\title{
ЧТО ПИСАЛИ ЕВРОПЕЙСКИЕ УЧАСТНИКИ ОРЕНБУРГСКОЙ ЭКСПЕДИЦИИ О КАРАКАЛПАКАХ ХVIII В.?
}

\author{
Сапарниязов Азизбек Турганбаевич \\ Каракалпакский научно-исследовательский институт гуманитарных наук \\ Каракалпакского отделения Академии наук Республики Узбекистан, \\ Младиий научный сотрудник
}

\section{WHAT DID THE EUROPEAN PARTICIPANTS OF THE ORENBURG EXPEDITION WRITE ABOUT THE KARAKALPAKS OF THE XVIII CENTURY?}

\author{
Saparniyazov Azizbek Turganbaevich. \\ Karakalpak Research Institute of Humanities \\ of the Karakalpak Branch of the Academy of Sciences of the Republic of Uzbekistan. \\ Junior Researcher.
}

Аннотация. В данной статье предпринята попытка проанализировать работы европейских участников Оренбургской экспедиции, в целях выяснения истории каракалпаков XVIII века. Определены основные направления интересов немецких и английских исследователей. Приводятся некоторые фрагменты касательно этнонима и политической истории каракалпаков.

Annotation. This article attempts to analyze the work of the European participants of the Orenburg expedition, in order to clarify the history of the Karakalpaks of the XVIII century. The main areas of interest of German and English researchers are identified. Some fragments concerning the ethnonym and political history of the Karakalpaks are given.

Ключевые слова. каракалпаки XVIII века, материалы Оренбургской экспедиции, сообщения европейских путешественников.

Keywords. Karakalpaks of the XVIII century, materials of the Orenburg expedition, reports of European travelers.

В условиях развития мировой исторической науки, в архивах и рукописехранилещах различных стран мира накопилось большое количество материалов, содержащие сведения по истории народов Центральной Азии в целом, и каракалпаков в частности. Во всем мире степень изученности этих источников разнообразна, то есть некоторые из них уже исследованы и изучены достаточно, другие только сейчас привлекается в научный оборот, следующие малоизвестны широкому кругу историков, а последние еще предстоит обнаружить.

В настоящее время восполнение новыми историческими материалами существующих пробелов в истории каракалпакского народа до сих пор остается насущней задачей отечественных историков.

В материалах Оренбургской экспедиции 1734-1744 гг. содержатся наиболее ранние сведения о каракалпаках, поэтому любые исторические и этнологические исследования, так или иначе, начинаются с этого источника. Мы думаем, что на базе извлеченных из документов Оренбургской экспедиции ценных сведений можно воссоздать более цельную картину жизни каракалпакского народа. Этим и обусловливается большая актуальность изучения различных материалов Оренбургской экспедиции, в исследовании истории каракалпаков. Некоторые из этих материалов, до сих пор не привлечены в научный оборот, хотя потребность в этом становится все более настоятельной.

Историография по теме исследования социально-экономической и политической истории каракалпаков XVIII в. насчитывает сотни публикаций. Существующие источники достаточно разнохарактерны как по жанру и уровню теоретического обобщения, так и спектру поднимаемых в них вопросов. Поэтому мы можем разбить их на несколько групп: 1) Архивные источники; 2) Опубликованные источники (имперский период); 3) Опубликованные источники (советский период); 4) Исследования постсоветского периода.

В данной статье, уделяя внимание ко второй группе источников, попытаемся определить историю каракалпаков на основе материалов европейских участников Оренбургской экспедиции. К этой группе относятся сообщения английских, немецких и других европейских путешественников, членов дипломатических миссий и других лиц Оренбургской экспедиции, содержащие сведения о каракалпаках.

Письменные данные европейских участников Оренбургской экспедиции, наряду с другими материальными артефактами, могут показать неизвестные страницы истории каракалпаков рассматриваемого периода. Здесь сохранились редкие и своеобразные сведения о каракалпаках и других народах Центральной Азии.

Наблюдения, отражение и понимание действительности истории и этнографии каракалпакского народа в записях иностранцев неоднозначны. Но подобное разнообразие мнений, отношений к каракалпакам, отличавшимся от европейцев своим образом жизни, обычаями и нравами, представляет значительный интерес, ибо дает возможность увидеть историю каракалпаков глазами современников с разных сторон. В этом большая ценность записок и дневников иностранных путешественников по Средней Азии. 
Английские участники Оренбургской экспедиции Дж.Эльтон, Дж.Кэстль, Р.Хоуг и др. находясь среди народов Центральной Азии, в том числе каракалпакского народа собирали разного рода сведения о них [1].

В 1740 г. английские купцы Томпсон и Гогг одновременно с Гладышевым были в Хиве и дали в своем отчете краткие сведения о населении берегов Аральского моря [2].

В составе Оренбургской экспедиции находились и немецкие исследователи. Например, Г.Ф.Миллер [3], И.Э.Фишер [4] изучали вопросы этногенеза каракалпаков.

Трудами европейских авторов являются дневники, путевые заметки, мемуары и, наконец, обобщающие работы. Некоторые из дневниковых записей западных путешественников, побывавших в Средней Азии, вошли в сборники, изданные в различное время в Англии, США, Франции и Германии [5].

Необходимо отметить, что сведения о каракалпаках в этих источниках, хотя и фрагментарные, и они упоминаются только наряду с другими народами Центральной Азии, в них приводятся важная информация, имеющая большое значение для выяснения истории каракалпаков рассматриваемого периода. Другая значимость этих материалов состоит в том, что с их помощью возможно углубление нашей источниковой базы, что дозволяет устанавливать и решать новые научные проблемы.

Вначале XVIII в. европейцы мало что знали о каракалпаках, жизни каракалпаков, их занятии, культуре и быте. Однако стратегические цели Российского государства, к тому же заинтересованность к среднеазиатским народностям, в том числе и каракалпакам, настойчиво призывали широкого их исследования. В политических проектах царской России территория каракалпаков занимала особое место в силу своего рентабельного географического расположения. Поэтому колонизаторская политика царской России, требовала от Оренбургской экспедиции всестороннего изучения населения Центральной Азии.

В ряде случаев европейцы рассказывают о таких событиях, которые без их известий остались бы тайной для позднейших поколений. Например, некоторые вопросы этнической культуры и истории каракалпаков (самоназвание каракалпаков, их этническая территория, кочевья и родоплеменная структура) рассматривались в основном немецкими учеными.

Участник Оренбургской экспедиции Г.Ф.Миллер в своей научной деятельности уделил достаточное внимание вопросам изучения каракалпакского народа. Миллер проник в ориенталистику посредством исследования древнерусских архивных документов касающиеся азиатских этносов. Он отмечал, что «Черные Клобуки есть Российское название, данное народу может статься по тому, что оный таковые Клобуки носил, так как и ныне называем мы некоторый народ каракалпаками. Хотя сия и ничего не доказывает, однако не невероятно, что народ, коего происхождение неизвестно, получил начало свое от остатков другого народа, который в то самое время исчез, как оный появился» [3:83].

Другой участник, по происхождению тоже немец, исследователь, член Санкт-Петербургской Академии наук и профессор древности и истории Иоганн Эбергард Фишер пишет следующее: «Откуда имя Калмык? Имя «Калмык» происходит бесспорно от некого рода шапок, употребляемых у элутов, и которые на татарском языке калпаками называется. Бухарские и Хивинские татары называют Манкат-топ своих одноверцев каракалпаками, то есть носящими черные шапки» $[4: 23,24]$.

Мы полагаем, что в этот период природа Приаралья была довольно жаркой. К концу весны лучи палящего солнца сжигали в этих краях поверхность земли. Свидетельство об описании климата и состоянии каракалпакского народа составляет данные П.Рычкова, где он пишет: «Живучи тут от солнечного жара, как мужеск так и женск пол носили на головах своих кара-колпаки, то есть черные шляпы, отчего и звание свое получили» [6:173].

В 1986 г. каракалпакский ученый Д.Айтмуратов опубликовал работу, посвященную этимологическому анализу многих тюркских этнонимов. В данной книге автор предложил их новую интерпретацию, подтверждая свои выводы филологическими доказательствами и историко-лингвистическими материалами. По поводу вышеуказанного вопроса он утверждал, что современный этноним «каракалпаки» и этноним «черные клобуки», имеющие одно и то же значение черной пряди волос, хохла, кос, черного волоса, можно считать отождествленными [7:55].

Таким образом, согласно данным Оренбургской экспедиции термин каракалпак - тюркское слово, и означает «черная шапка», т.е. народ, носивший черную шапку. С течением времени данная лексема трансформировалась и, приняв этническое содержание начал использоваться в качестве этнонима.

В XVIII в. наряду с немецкими исследователями в деле собирания всевозможных информации о среднеазиатском регионе немалая работа была сделана англичанами, которые находились в службе российского государства. Например, в Оренбургской экспедиции участвовал английский капитан морской службы Джон Эльтон. Он старался не упускать подходящих моментов для бесед с различными «татарами», бродившими и жившими на территории неисследованных стран.

В результате долгих наблюдений Эльтон отмечает, что «безопасная дорога в Бухару» проходит не через казахскую территорию, а «вниз по реке Волге, после через Каспийское море и Астрабад или через другой порт, находящийся в юго-восточной части Каспийского моря» [8:15]. 
Также он принимал участие в организации картографических работ, составил карты восточного побережья Каспийского моря.

В Оренбургской экспедиции рядом с Эльтоном в течение нескольких лет находился и английский художник Джон Кэстль. Его путешествие было достаточно результативным в смысле научно-познавательном. Сегодня «Дневник» Джона Кэстля является историко-этнографическим источником, представляющим большой научный интерес. Этот «Дневник» был опубликован в 1784 г. как дополнительное приложение к «Материалам по русской истории» [9].

Согласно данным Кэстля территория сегодняшней Центральной Азии тогда изобиловала животными, растениями и полезными ископаемыми. По словам Кэстля, во время весеннего прилива Сырдарья выбрасывала на берег золотые пески, откуда добывали золото бухарцы, платя за это дань казахам $[9: 7,8,78,112,118]$.

Кроме Эльтона и Кестля в составе Оренбургской экспедиции находились и другие англичане, которые также занимались сбором разнородных информаций о народах Центральной Азии.

Одним из таких участников был Рейнольд Хоуг. Он совершил свое путешествие из Оренбурга в Хиву и Бухару в 1740 г. и вернулся оттуда в Самару через год в июле 1741 г. После приезда Рейнольд Хоуг в канцелярии Оренбургской комиссии детально поведал о своем странствии, дав «о тамошних своих усмотрениях объяснение» [10:137].

Он сообщил, что караванная торговля русских купцов в Хиве может быть выгодна и безопасна при условии «охранения» ее казахскими владельцами. Рассказал и о том, что в хивинской торговле казахи занимали преобладающее место, и они иногда выступали даже посредниками в торговле с каракалпаками.

Немного спустя, Хоуг вторично отправляется к каракалпакам. Представители царской власти стремились привлечь хивинцев, казахов и каракалпаков к торговле в Оренбурге. Они пользовались каждым шансом для развития в казахской степи караванной торговли, а затем продолжать завоевательную политику вглубь. В этих целях вторичная поездка Рейнольда Хоуга к каракалпакам была сочтена не противоречащей колониальным целям царской России.

Об этом в канцелярии Оренбургской комиссии было записано: «Из Самары он, Хоуг, отправился, получая определенные ему для торгу на счет его казенные деньги двести рублей, грамоты к Абулхаир хану, к каракалпакским старшинам Уразак батыру и прочим, и к кайсацкому Джаныбек батыру, также и указ с просчетом, изданном ему секретным наставлением того 1741 года августа около третьего числа» [10:206].

Эти «секретные наставления» состояли из 11 пунктов, вменявших англичанину в обязанность выяснить спрос и покупательскую способность, статьи торговли каракалпаков, обследовать их землю, подробно описывать горы, реки и речки, озера и озерки, внимательно осмотреть побережье Аральского моря (пригодность его к хлебопашеству) и все места, где можно было бы основать пристань.

Из Самары через крепость Озерное Хоуг на восьмые сутки прибыл в район нынешнего Соль-Илецка, а оттуда в сопровождении людей старшины Найманского рода Кунакай-батыра к Джаныбеку, зимовавшему близ урочища Каракаил. Затем он переехал Сырдарью и 22 декабря «прибыл на каракалпацкую землю» [10:211].

6 января Рейнольд Хоуг встретился с каракалпакским старшиной Уразак батыром в урочище Карамул, близ устья реки Куван-Дарьи, впадающей в Аральское море. Здесь Хоуг получил информации об угоне людьми Абулхаир хана лошадей каракалпаков. 17 января был у Абулхаира, однако он был принят ханом сугубо официально, который ничего не предпринял для розыска и возвращения прежде ограбленных его товаров.

Хоуг знакомился с бытом каракалпаков, получил согласие Уразак батыра на торговлю в Оренбурге и на отправление его «водяным ходом» по Аральскому морю в Хиву. Все эти сведения были записаны со слов Хоуга в канцелярии Оренбургской комиссии в июне 1742 г. [10:211].

Разумеется, всех вышеуказанных источников невозможно назвать чисто научными исследованиями, так как в них материалы лишь собирались, но не классифицировались и не подвергались специфическому разбору с позиций научной рациональности. Кроме того, среди этих материалов не было работ, специально посвященных истории каракалпакского народа. Тем не менее, на основе извлеченных из европейских письменных источников ценных сведений можно воссоздать более цельную картину жизни каракалпакского народа XVIII столетия. Этим и обусловливается большая роль европейских письменных источников в исследовании истории каракалпаков.

\section{СПИСОК ЛИТЕРАТУРЫ}

1. Hanway J. An historical account of the British trade over the Caspian Sea: with a journal of travels from London through Russia into Persia and back.... In 4 Vols. London: 1753; Hutton J. Central Asia. London: 1875.

2. Берг Л. Аральское море. Санкт-Петербург: Типография М.М. Стасюлевича, 1908.

3. Миллер Г. О народах издревле в России обитавших. С немецкого на Российский язык переведено Иваном Долинским. Санкт-Петербург: 1773.

4. Фишер И. Сибирская история с самого открытия Сибири до завоевания сей земли Российским оружием. Санкт-Петербург: 1774.

5. Murray H. Historical account of discoveries and travels in Asia, from the earliest ages to the present times. Vols. 1-3. Edinburg: 1820; Maclean F. A person from England and other travelers. London: 1958; Jenseits des steinernen Tores 
Entdeckungsreisen Sibirien in 18 und 19 Jahrhunderts... Berlin: 1963; Wilson F. Muscovy Russia through foreign eyes 1553-1900. New York, Washington: 1970; Beard M. European Travelers in the Trans-Caspian before 1917 // Cahiers di Monde Russe et Sovietique. Paris: 1972. Vol. 13. № 4. C. 590-596.

6. Рычков П. Топография Оренбургская, то есть: обстоятельное описание Оренбургской губернии / Сочиненное коллежским советником и Императорской Академии наук корреспондентом Петром Рычковым. Часть 1. Санкт-Петербург: при Императорской Академии наук, 1762.

7. Айтмуратов Д. Тюркские этнонимы: каракалпак, черные клобуки, черкес, башкурт, кыргыз, уйгур, тюрк, печенег, сак, массагет, скиф. Нукус: Каракалпакстан, 1986.

8. Hutton J. Central Asia. London: 1875.

9. Journal von der Ao. 1736 aus Orenburg zu dem Abul-Geier Chan der Kirgis-Kaysack Tartarischen Horda aus freiem villen und bloss zu dem bestem des russischen reiches untergenommen höchft nothigen und zwar gefürlichen doch glücklich volbrachten Reise dargestellet durch John Castle emen Englander und gewesenen Kunstmaller bei der Orenburgischen Expedition // Materialen zu der Russischen Geschichte zeit Tode Kaisers Peter des Grossen Zweiter. Teil. 1730-1741. Riga: 1784.

10. Казахско-русские отношения в XVI-XVIII веках. (Сборник документов и материалов). Алма-ата: АН Казахской ССР, 1961. 